\title{
Grenzen aan de groei
}

Naar het oordeel van de visitatiecommissie geneeskunde die in 2003 de medische opleidingen heeft bezocht, gaat het in het algemeen goed met de artsopleiding. Zo blijkt uit een - in kleine kring verspreid concept van het rapport dat op 10 juni 2004 verschijnt. Dat neemt niet weg dat er, behalve opleidingsspecifieke aandachtspunten, ook generale problemen bij het hedendaagse medische onderwijs worden gesignaleerd. Als meest dramatische bedreiging voor de kwaliteit van de opleiding wordt de drastische ophoging van de numerus fixus genoemd. En daar heeft de commissie een punt.

De verdubbeling van de eerstejaars instroom in ruim 10 jaar tijd - een groeitempo van ongekende omvang voor het medisch onderwijs - die gepaard is gegaan met een handhaving of vergroting van kleinschalig onderwijs, was niet eenvoudig op te vangen. De opleidingen kennen nu een instroom van gemiddeld 350 eerstejaars. Er zijn ook universitaire opleidingen - rechten, psychologie - die ook veel eerstejaars trekken. Wie deze vergelijking maakt, moet zich bedenken dat vrijwel geen enkele andere opleiding die eerstejaars ook voor $80 \%$ tot $90 \%$ tot het eind toe vasthoudt en moet accommoderen. Binnenkort kent Nederland doorlopend 12.000 tot 15.000 medische studenten. $\mathrm{Zij}$ volgen probleemgestuurd medisch onderwijs in kleine groepen, gesprekstrainingen en practica en zij moeten getoetst worden met stationsexamens en hun plaatsen vinden in klinische stages. Collegeonderwijs is - terecht - geen dominante onderwijsvorm in de medische opleiding.
De opleidingen hebben niet zelf gekozen voor dit groeitempo. De numerus fixus wordt door de minister bepaald en weerspiegelt politieke keuzes. Het is een knop aan de gezondheidszorg die voor de politiek bedienbaar is en dus graag heen en weer gedraaid wordt, al naar gelang de behoefte aan kostenbeheersing of juist aan een toegenomen vraag naar artsen. Het is te prijzen dat de opleidingen de recente groei zó hebben kunnen opvangen dat een visitatiecommissie het huidige medische onderwijs in Nederland kenschetst als een heuvellandschap zonder diepe dalen. Maar de inspanning om dat te realiseren is dan ook groot. Op nogal wat locaties wordt er in nieuwbouw geïnvesteerd om het onderwijsvolume te kunnen herbergen. Alle niet-universitaire ziekenhuizen van enige betekenis worden bij het klinisch onderwijs betrokken en zij vragen daar nu 2 tot 6 keer zoveel vergoeding voor als enkele jaren geleden. De opleidingen hebben deze affiliatie nodig en dat weten ze. Het is terecht dat onderwijsinspanning beter beloond wordt dan vroeger, maar de combinatie van de grote studentenaantallen en een hogere vergoeding voor een toch al dure opleiding maakt de financiering een punt van zorg.

Een ander punt van zorg is de werving van voldoende geëquipeerde en gemotiveerde staf. Schaarste aan artsen - reden om er meer op te leiden - geldt ook bij onderwijzend medisch personeel. De beschikbare staf moet steeds meer voor onderwijs en opleiding worden ingezet. Niet alleen voor studenten maar ook voor assistenten 
in de vervolgopleiding, vanwege ook hun toegenomen aantal en vanwege de hogere kwaliteitseisen die - terecht - ook hier worden gesteld. Onderwijs is voor medici geen vanzelfsprekende zaak en de vraag is of dat niet zou moeten. Zolang de overdracht van kennis aan volgende generaties niet als Hippocratische kernopdracht van iedere medicus wordt gevoeld maar als een oneigenlijke taak, zal op de werkvloer het opleiden tot spanning leiden bij een toenemende onderwijsbehoefte, zeker bij een schaarste aan dokters. Maar ook in de basisvakken wordt een personeelsprobleem gesignaleerd. Het arbeidsmarktperspectief voor de fysioloog en de anatoom - essentiële vakken voor de medische studie - wordt als zo ongunstig gevoeld dat er gevreesd wordt voor grote bezettingsproblemen op deze terreinen. ${ }^{1-2}$

Aan het oplossen van tekorten van artsen kan en moet de medische opleiding natuurlijk bijdragen en die bijdrage wordt naar vermogen geleverd. Ook de belangstelling voor geneeskunde is nog steeds overweldigend. Op 5 maart 2004 hadden zich 3664 scholieren aangemeld voor de geneeskundestudie. Voor alle andere 46 universitaire opleidingen tezamen hadden zich tot op die dag 6821 scholieren aangemeld, nog geen tweemaal zoveel dus. Van alle acht medische opleidingen had de minst populaire locatie altijd nog meer aangemelde studenten dan de meest populaire van de 240 overige universitaire opleidingen (rechtsgeleerdheid in Utrecht), met uitzondering van de diergeneeskunde.

Het is echter goed om ook de oorzaken van het dreigend artsentekort hierbij te betrekken en de vraag is of alle heil van een vergroting van de opleidingscapaciteit moet komen. Nederland heeft inderdaad relatief weinig artsen per hoofd van de bevolking (Nederland heeft minder artsen dan andere EU-landen. Http://medisch- contact.artsennet.nl/themes/36, 09-03-2004). Daarnaast groeit de vraag naar gezondheidszorg, onder andere door de vergrijzing. Maar een belangrijke oorzaak is ook het toenemend aantal afgestudeerden dat voortijdig uit het beroep stapt, dat parttime gaat werken of dat er helemaal niet in gaat werken. ${ }^{3}$ Een universitaire opleiding dwingt mensen niet om daadwerkelijk dat vak te gaan uitoefenen en het is steeds gebruikelijker om ook de geneeskunde niet als levensvervulling te zien.

Voor een steeds maar groeiende fixus is wel voldoende belangstelling bij scholieren en de opleidingen zouden daarom nog groter kúnnen worden, gesteld dat er tijdig in voldoende geld, ruimte en gekwalificeerd personeel kan worden voorzien en de kwaliteit niet wordt aangetast. Maar het macro-rendement van de opleiding neemt in hoog tempo af; iedere euro in de medische opleiding levert steeds minder gezondheidszorg op. Een instelling die nu 250 studenten aflevert die gemiddeld 25 jaar 20 uur in de week zullen werken, is nog niet half zo rendabel als toen zij in 1975150 studenten afleverde die gemiddeld 35 jaar 50 uur in de week zouden gaan werken. Dat rendement zal verder dalen bij een verder toenemende instroom aan de voorkant zonder dat een verder verlies aan de achterkant wordt gestelpt. Voor de oplossing van het artsentekort is het dus minstens zo belangrijk om het beroep aantrekkelijk te houden voor de afgestudeerden en ook om gaten in de zorg op een andere manier te vullen; deze knoppen worden nog onvoldoende bediend. Pas dan is ook verdere investering in de kwantiteit van het onderwijs de moeite waard.

Wie denkt: "We hebben zóveel dokters nodig en er zijn zóveel scholieren die dat willen worden, laten we ze zo snel mogelijk massaal opleiden" ziet dus een paar 
factoren over het hoofd. De grens aan de groei van de opleidingscapaciteit lijkt te zijn bereikt en andere wegen zijn nodig om de problemen in de gezondheidszorg aan te pakken.

\section{Olle ten Cate}

\section{Literatuur}

1. Karemaker JM, Coebergh JWW. De toekomst van medisch onderwijs in de UMC's. Mediator 2004; 15:3.

2. Coebergh JWW, Karemaker JM, Oosterhuis JW. Bottleneck in de zorg. Noodsignaal over opleidingsplaatsen in UMC's. Med Contact 2004;59(3): 60-2.

3. Berg MJ van den, Bakker DH de, Kolthof ED, Cardol M, Brink-Muinen A van den. De werkdruk van de huisarts - Zorgvraag en arbeidsduur in 1987 en in 2001. Med Contact 2003;58(26/27): 1054-6. 